\title{
An Overview of Bacterial Leaf Blight Disease of Rice and Different Strategies for its Management
}

\author{
Sumit Shekhar*, Diksha Sinha and Anita Kumari \\ Department of Plant Pathology, Bihar Agriculture College, \\ Bihar Agricultural University, Sabour, Bhagalpur, Bihar, India - 813210 \\ *Corresponding author
}

\section{A B S T R A C T}

\begin{tabular}{l} 
Ke y w o r d s \\
BLB, Xoo, Rice, \\
Host resistance, \\
$\begin{array}{l}\text { Disease } \\
\text { management }\end{array}$ \\
Article Info \\
$\begin{array}{l}\text { Accepted: } \\
18 \text { March } 2020 \\
\text { Available Online: } \\
10 \text { April } 2020\end{array}$ \\
\hline
\end{tabular}

Rice crop accounts for nearly a third of the total area under food grains in India and is the staple food for a significant portion of the world's population. Widely varying factors influence the growth of rice in different rice growing areas and render the crop susceptible to various pathogenic and non-pathogenic diseases, resulting in extensive damage of grain and straw yield. Bacterial leaf blight disease of rice caused by Xanthomonas oryzae pv. oryzae (Xoo) is a serious menace to rice production in India, besides other rice producing countries. Elaborate studies have been conducted on the genetics of host-pathogen interaction of BLB and exploitation of host resistance to combat the disease. This article comprehensively reviews the etiology, symptomatology, pathogen biology, disease development, disease cycle, epidemics and epidemiology, geographical distribution and strategies for the disease management viz., exploitation of host plant resistance, cultural, physical, chemical and biological control.

\section{Introduction}

Rice (Oryza sativa $\mathrm{L}$ ), is consider as queen of the cereal crops because of its importance as staple food of about half of the world's population (Qudsia et al., 2017). The bacterial leaf blight disease of rice caused by Xanthomonas oryzae pv. oryzae and huge losses in form of quantitative and qualitative of rice. In world, due to this disease yield loss was estimated approx 50\% (Shekhar and Kumar, 2020) and in India 81.3\% (Prasad et al., 2018; Swati et al., 2015). Several biotic and abiotic factors are the main constraint for reducing the production and productivity of rice.

Among the biotic factors, diseases (26\%), insects (20\%) and weeds (23\%) are affecting large amount of yield loss, both in terms of quality and quantity. Rice crop is affected by more than 36 fungal, 21 viral and 6 bacterial diseases. The major diseases affect the production and productivity of rice crop 
worldwide due to infection of various fungi, bacteria and viruses (Jena and Mackill, 2008).

Among the different diseases of rice, brown leaf spot (Helminthosporium oryzae), blast (Pyricularia grisea), sheath blight (Rhizoctonia solani), sheath rot (Sarocladium oryzae), bacterial leaf blight (Xanthomonas oryzae pv. oryzae), rice tungro virus (Virus), false smut (Ustilaginoidea virens), leaf scald (Rhynchosoprium oryzae), bakanae disease (Fusarium moniliforme), grain discoloration (Drechslera oryzae, Fusarium spp.) are more prevalant (Mustafa et al., 2013). Among different diseases affecting rice, bacterial leaf blight (BLB) caused by Xanthomonas oryzae pv. oryzae highly destructive in nature.

\section{Historical background}

Bacterial leaf blight disease caused by Xanthomonas oryzae pv. oryzae is one of most destructive and oldest diseases of rice recorded in the world. It was first time reported farmers of fukuoka area of Japan in 1884-1885 (Yamanuki et al., 1962: Tagami and Mizukami, 1962). In early studies showed that the bacterial leaf blight disease was a physiological problem due to the acidic soils in rice growing areas (Yoshida and Muko, 1987). According to Takaishi, (1908) masses of bacteria were isolated from the (acidic) turbid dew drops on infected rice leaves, were acidic in reaction and disease was reproduced by inoculating healthy leaves with these drops (Nino liu et al., 2006). The causal agent was first isolated by Hori and Bokura, in 1911 and named as Bacillus oryzae and Iyeda and Ishiyama renamed as Pseudomonas oryzae (Gnanamanickam et al., 1999, Chauhan and Vaishnav, 1980) and later Xanthomonas oryzae. In 1978, it was reclassified as Xanthomonas campestris pv. oryzae. Southern China, disease was again characterized as distinct from bacterial leaf blight and called bacterial leaf streak in 1957.
The bacterial leaf blight was named as Xanthomonas oryzicola and it was renamed Xanthomonas translucens f. sp. oryzae by Goto in 1964. In 1990, it was named as Xanthomonas oryzae pv. oryzae (Nino liu et al., 2006).

In India, during 1951, a very devastating and widespread disease of rice was found in different areas of Maharashtra state which was first reported caused due to bacterial leaf blight by Srinivasan et al., 1959. The disease was initially recorded in Maharashtra state but occurrence of epidemic in the Shahabad district of Bihar in 1963 established the destructiveness of the disease all over India (Srivastava, 1967).

\section{Geographical distribution}

In Japan, this disease has been referred to as "white withering disease" since 1881 where it was previously recorded in various localities of southern Japan. It was first reported by farmers of Fukuoka area of Japan in 1884. Later on, it was reported from all over the world viz. Japan, Africa, South America, Korea, Indonesia, Taiwan, China, Mexico, Thailand, India (Maharashtra) Sri Lanka, Vietnam, Philippines, Bangladesh, Australia, Malaysia, Cambodia and Latin America which signifies the wide occurrence of this disease around the world (Srinivasan et al., 1959, Ou, 1977).

Bhapkar et al., (1960) referred Xanthomonas oryzae pv. oryzae (Xoo) is one of the most catastrophic diseases of rice in Asia. In India, during 1951 a very important disease of rice was found on widespread basis in different areas of Maharashtra state which was first reported by Srinivasan et al., in 1959. Most important rice growing states viz. Andhra Pradesh, Punjab, Haryana and western Uttar Pradesh states of India, major epidemic of this disease occurred during 1979 -1980. 
This disease occurred in epidemic form in the Shahabad district of Bihar in 1963 (Srivastava, 1967). According to Mew 1987 the extent of yield loss depends on locality, season, weather, cultivar and application of high amount nitrogen fertilizer that tends to yield loss about $60 \%$.

\section{Economic importance of bacterial leaf blight}

Bacterial leaf blight of rice has been epiphytotic in many places of the world and yield loss was estimated approx 50\% (Kulkarni and Jahagirdar, 2011). According to Patel et al., 2009, it is one of most devastating disease in both tropical and sub-tropical region in the world. In tropical countries viz. India, Philippines, Indonesia, it is more destructive because of resulting kresek syndrome of bacterial leaf blight, which affects 3-4 weeks of transplanted seedling of rice and yield loss reached upto $60-75 \%$. This disease affects grain quality by interfering with maturation depends on weather, location and varieties. Crop losses of 10-20 per cent in moderate conditions or severe losses of up to 50 per cent in highly conducive conditions have been recorded in several Asian and Southeast Asian countries (Sharma et al., 2017; Moria et al., 2017).

Yield loss depends on virulence of pathogen, host pathogen relationship and different environment factors and reported that yield loss from 20-74\% (Singh et al., 2015). The yield loss due to this disease is $6-60 \%$ in terms of quantity and quality. About 22,000 $1,10,000$ MT losses were reported in Japan in 1954 due to the bacterial leaf blight disease of rice. In Philippines, losses were reported in resistant crop up to $9.5 \%$ in wet condition whereas for susceptible crop, losses were found $22.5 \%$ in wet and $7.2 \%$ in dry condition. In West African countries, the disease incidence ranged from $70-85 \%$ and yield losses ranged from $50-90 \%$ in the severely infected fields (Kumar et al., 2017). According to Khan et al., (2015) in case of severe infection, 50\% yield reduction and about $10-12 \%$ yield reduction in mild infection. Yield losses as high as $81.3 \%$ have been reported due to this disease in India (Prasad et al., 2018; Swati et al., 2015).

This disease is endemic because of high nitrogen level, close plant spacing and high moisture condition (Mandal et al., 2017; Parthasarathy et al., 2014). Rafi et al., (2013) reported that BLB disease of rice affect filling of the grains and emergence of panicles, about $28-30 \%$ yield reduction was observed in susceptible cultivars. This disease may weaken the seedling and in older plants the loss of grain may be $4.5-29.1 \%$. Mubassir et al., (2016) revealed that yield loss was up to $80 \%$ and depend on the crop stage, environmental condition and susceptibility.

Bacterial leaf blight is a typical vascular disease, systemic in nature (Sharma et al., 2017). This bacteria infected at all stages of the rice and manifested by either Kresek or leaf blight symptom. This infection due to this disease occurs after 3-4 weeks of transplanting and later at booting or heading stage and also bacterium can infect at flowering stage (Bala et al., 2017). Infection of this disease in rice is also found at the tillering stage, resulted sometimes $100 \%$ yield losses (Shahbaz et al., 2016; Parthasarathy et al., 2014).

\section{The disease}

Bacteria leaf blight (BLB) is vascular disease resulting in systemic infection. Xanthomonas oryzae pv. oryzae enters either through wounds or hydathodes, multiplies in the epitheme cell and move to the xylem vessel. The symptoms of this disease include Kresek (wilting) and blight of the leaves (Nino liu et 
al., 2006). Kresek symptoms are more destructive resulted of systemic infection that commonly occurs in tropics in young plants and during the tillering stage of susceptible cultivars. Plants less than 21 days old are most susceptible and $28-34^{\circ} \mathrm{C}$ temperature favor Kresek development (Gnanamanickam et al., 1999; Kumar et al., 2009; Mew et al., 1969). In kresek phase due to blockage of nutrient transfer from root to different parts of plant resulting in pale yellow symptoms appears and finally wilting of the plant. Surviving plants look like stunted and yellowing (Mew, 1987, Chauhan and Vaishnav, 1980).

Leaf blight symptoms generally occur from maximum tillering stage and onwards. Damage due to bacterial leaf blight, ranges from $20-30 \%$ and as high as $50 \%$ (Nino liu et al., 2006; Habarurema et al., 2013). Leaf

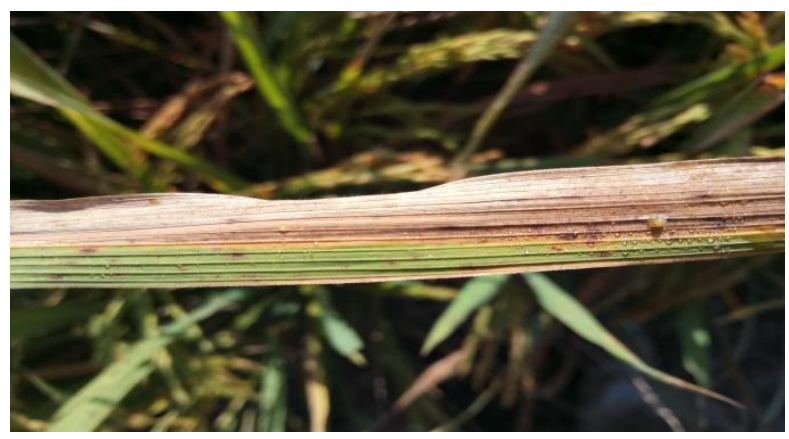

Fig.1 Oozing of Xanthomonas oryzae pv. oryzae in rice plant.

Causal bacterium: xanthomonas oryzae pv. oryzae

$\begin{array}{lll}\text { Kingdom } & : & \text { Prokaryote } \\ \text { Phylum } & : & \text { Proteobacteria } \\ \text { Class } & : & \text { Gammaproteobacteria } \\ \text { Order } & : & \text { Xanthomonadales } \\ \text { Family } & : & \text { Xanthomonadaceae } \\ \text { Genus } & : & \text { Xanthomonas } \\ \text { Species } & : & \text { oryzae. }\end{array}$

blight symptoms favoured by warm temperatures $25-30^{\circ} \mathrm{C}$, high humidity, rain and deep water. Leaf blight symptoms are characterized by wavy elongated lesion, which develop along the leaf margins (Khan et al., 2015). They start as small water soaked stripes from the tips where water pores are found and rapidly enlarge in length and width, forming a yellow lesion with a wavy margin along the edge. Later on, diseased areas turn white to grey. These lesions can develop on one or both sides of the leaf and occasionally along the midribs (Qudsia et al., 2017; Mew, 1987) (Fig. 1 and 2).

The sign of Xanthomonas oryzae pv. oryzae is bacterial ooze and can be seen on the margins or veins of the freshly infected leaf under moist conditions in morning hours and a source of secondary inoculums (Mew et al., 1993; Nino liu et al., 2006).

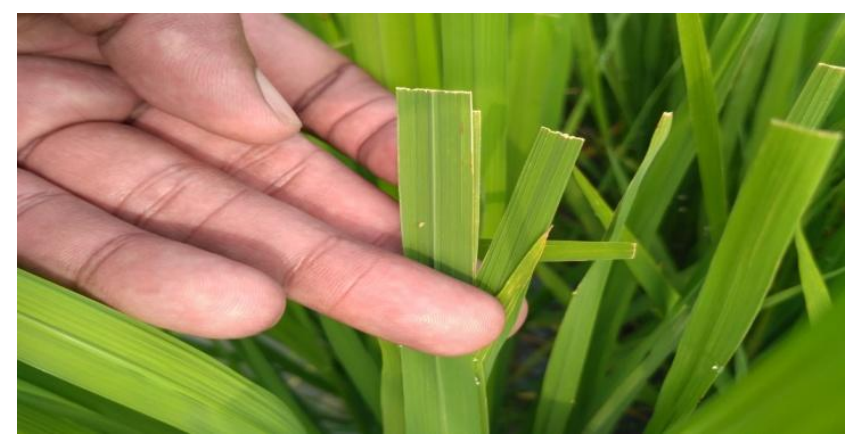

Fig.2 Symptoms of Bacterial leaf blight in rice plant.

\section{Morphology and life cycle of xanthomonas} oryzae pv. oryzae

The Xanthomonas oryzae pv. oryzae is obligate aerobic, non-spore forming, rod shape, gram negative, round ended, motile with single polar flagellum, slime-producing. Individual cells vary in length from approximately $0.7 \mu \mathrm{m}$ to $2.0 \mu \mathrm{m}$ and width from $0.4 \mu \mathrm{m}$ to $0.7 \mu \mathrm{m}$. Optimum temperature for Xanthomonas growth is between $25-30^{\circ} \mathrm{C}$ (Gnanamanickam et al., 1999). It is catalase- 
positive, unable to reduce nitrate and a weak producer of acids from carbohydrates. Xanthomonas colonies are formed on solid media containing glucose are round, convex, mucoid and yellow colour is due to production of the pigment xanthomonadin. Xanthomonas oryzae cells produce copious capsular extracellular polysaccharide (EPS). This EPS is important for the formation of droplets or stands of bacterial exudates from infected leaves, producing protection from dessication and resulted wind and rain borne dispersal (Nino liu et al., 2006).

Xanthomonas can survive in the soil for 1-3 months depending on the soil moisture and acidity. In tropical region, due to high temperature, humidity and an abundance of host plants, Xanthomonas persists throughout the year. This disease is more likely to occur during the monsoon season of the south-east Asian and Indian oceans particularly from June to September. Kumar et al., (2017) reported that the primary inoculum of disease in rice crop occurs due to Xanthomonas oryzae pv. oryzae (Xoo) infected rice planting seed, stem and plant parts left out after harvest.

Xoo enters through hydrathodes and wounds of the leaf tip and leaf margin of the rice leaves. Cells on the leaves surface may become suspended in guttation fluid as it exudes at night and enter the plant by swimming, or passively as the fluid is with drawn into the leaf in the morning (Nino liu et al., 2006; Mouria et al., 2017).

The Xanthomonas oryzae pv. oryzae is seed borne transmitted pathogen, although, transmitted through the seed has been not reported yet (Gnanamanickam et al., 1999). The wind, rain splash, birds, insects and human activities disperse the Xanthomonas from one place to other place. The Xanthomonas oryzae pv. oryzae survive on different hosts viz. Brachiaria mutica, Cenchus ciliaris, Cyperus difformis, $C$. rotundus, Cynodon dactylon, Echinochloa crusgalli, Leersia spp (Leersia hexandra, L. oryzoides), Leptochloa chinensis, Panicum maximum, Zizania aquatica, Z. palustris, Leersia. Oryzoides and Zizania latifolia in temperate region and Laptochloa spp. and Cyperus spp. in tropical region. In temperate regions, Xanthomonas can survive in the rhizosphere of weeds of the genera Leersia and Zizania as well as in the base of the stem and the roots of rice stubble in winter season (Nino liu et al., 2006).

Bacterium multiplies inside the vascular system and moves systemically to different plant parts. Xanthomonas oryzae pv. oryzae grows in plant and infected plant veins as well as the xylem that leads to blockage and wilting. Most favorable temperatures for Xoo growth ranges from $26-30^{\circ} \mathrm{C}$ and $20^{\circ} \mathrm{C}$ is ideal temperature for initial multiplication and growth. Xoo can tolerate $\mathrm{pH}$ ranges from 4 to 8.8 and optimum $\mathrm{pH}$ observed for its survival was reported 6-6.5 (Kumar et al., 2017).

\section{Management of bacterial leaf blight disease of rice}

At present, cultural, physical, chemical and biological control have been used to manage Bacterial leaf blight disease of rice.

\section{Cultural management}

Tabei (1960, 1967) reported that for management of the disease normally use of healthy seeds, infected stubbles, straws, leaves and weeds were removed from rice fields. Using suitable plant spacing, application of appropriate nitrogenous fertilizer (NPK), using modern irrigation system and by making the drainage systems as better as recommended. 


\section{Physical management}

Srivastava and Rao (1963, 1964) described that $95-100 \%$ eradication of Xanthomonas oryzae pv. oryzae, rice seeds was dipped into $0.07 \%$ solution of agrimycin by 12 hours and move out these seeds into water bath at $54^{\circ} \mathrm{C}$ for 30 minutes that reduces the bacterial leaf blight incidence in the rice field. Jain (1970) reported that effective control of bacterial leaf blight disease of rice, hot water treatment of rice seeds for about 30 minutes at $52^{\circ} \mathrm{C}$ proceeded by 8-10 hour of presoaking in water which was found to be the most effective against the bacterial leaf blight of rice. Zhang et al., (1996) described that 2-3 times washing of rice seeds in distilled water after that washing by the brine solution also minimized the disease and increased the germination percentage. Presoaking of rice seed in $50 \mathrm{ppm}$ suspension of zhonheshengmycin also minimized bacterial leaf blight disease incidence.

\section{Chemical management}

Elaborate studies have been conducted to determine the efficiency of combinations of different chemicals to manage the disease and reduce yield loss. Different combinations of antibiotics at varied concentrations have been recommended for disease inhibition by different workers over the years.

Singh et al., (2015) reported a combination of Streptomycin + Copper oxychloride @ 4\% was highly effective under in vitro condition. Other recommendations like Copper oxychloride $(0.25 \%)+$ Streptomycin sulphate 200 ppm (Kumar et al., 2009); Streptomycin @ 0.03\% and @ 0.05\% were also found effective (Prasad et al., 2018). In studies conducted by Patil et al., (2017) Streptocycline (streptomycin sulphate + tetracycline hydrochloride, 9:1) + Copper sulphate $\left(\mathrm{CuSO}_{4}\right) @ 1000$ ppm was more effective than Streptocycline @ 1000 ppm alone. Similar results were stated by Thimmegowda et al., (2012).

Jadhav et al., (2018) studied the in vitro effect of Carbendazim @ 500 ppm, Mancozeb @ 500 ppm and Streptocycline @ 250 ppm against Xanthomonas axonopodis pv. citri causing bacterial canker of kagzi lime and found Mancozeb @ 500 ppm to be highly effective followed by Streptocycline @ 250 ppm. Comparable results have been reported against Xanthomonas campestris pv. viticola causing bacterial leaf spot of grapes and bacterial leaf blight of rice (Gangwar, 2013). Inhibition by Mancozeb @ 500 ppm and Streptocycline @ 100 ppm was found to be at par (Kamble et al., 2017). Gangwar and Sinha (2012) found that 6\% inhibition of Xanthomonas in Carbendazim treatment as compared to control in laboratory condition.

Several strobilurins have been evaluated and found effective against BLB. Bala et al., (2017) reported the efficiency of Trifloxystrobin 25\% + tebuconazole 50\% @ $50 \mathrm{ppm}$ against $\mathrm{Xoo}$ under in vitro condition. Azoxystrobin 25 SC (Amistar) @ 1 ml/lwater performed better than Carbendazim 50 WP @ $1 \mathrm{gm} / \mathrm{l}$ water against bacterial leaf blight disease of rice (Swati et al., 2015).

Different recommendations of chemicals have been reported by workers against BLB in rice field. Treatments that resulted in minimum disease severity, least economic loss and maximum overall yield have been considered superior to others. Patil et al., (2017) tested different chemicals and found that the application of Streptocycline @ 0.5\% + copper oxychloride @ 2.5\% was most effective against bacterial leaf blight disease of rice. Other recommendations like Copper oxychloride @ 0.30\%, Streptomycin sulphate @ $0.05 \%$, Copper oxychloride $2.5 \mathrm{gm} / \mathrm{lit}$, Streptomycin sulphate $0.05 \mathrm{gm} / \mathrm{lit}+$ Copper 
oxychloride $0.5 \mathrm{gm} / \mathrm{lit}, \quad$ Streptocycline @ $0.025 \%$ + Copper oxychloride @ 0.1\%, Streptomycin sulphate @ $0.03 \%$ + copper hydroxide@ $0.25 \%$ and Streptocycline @ $0.03 \%$ + copper hydroxide @ 0.25\% were also found competent in disease control (Singh et al., 1980; Khan et al., 2005; Patel et al., 2009; Kulkarni and Jahagirdar, 2011; Thimmegowda et al., 2012; Prasad et al., 2018).

Jagtap et al., (2012) reported that disease control efficiency of Copper oxychloride $(0.25 \%)+$ Streptocycline 100 ppm was at par with Carbendazim @0.1\% + Streptocycline @ 100 ppm against Xanthomonas axonopodis pv. malvacearum causing bacterial leaf blight disease of cotton. Combination of Blitox $(0.3 \%)+$ streptocycline $(250 \mathrm{ppm})$ was found effective against Xanthomonas axonopodis pv. punicae causing bacterial leaf blight disease of pomegranate (Ashish et al., 2016). Copper oxychloride (1000 ppm) + Streptocycline $(250 \mathrm{ppm})$ have also been reported against Xanthomonas axonopodis pv. punicae spp. (Meena et al., 2017). Jarial et al., (2015) reported that Streptocycline @ $0.01 \%$ was most effective in reducing bacterial spot of bottle gourd caused by Xanthomonas cucurbitae.

Based on field trials conducted for two consecutive years, Chaudhary et al., (2012) reported that Bordeaux mixture alone and in combination with oxytetracycline and streptomycin was significantly effective against BLB in rice. Singh et al., (2015) found minimum disease incidence and maximum yield in plots treated with Oxytetracycline @ 75 gm/ha + Copper oxychloride@ @ 500 gm/ha which was as effective as Streptocycine @ $15 \mathrm{gm} / \mathrm{ha}+$ Copper oxychloride $500 \mathrm{gm} / \mathrm{ha}$ against bacterial leaf blight disease of rice. Biswas et al., (2009) observed that seed treatment with Streptocycline $(100 \mathrm{ppm})$ and three foliar application of Streptocycline in combination with Copper oxychloride was most effective in minimizing bacterial leaf blight disease incidence. Seedling root dip with streptocycline $(0.01 \%)+$ spraying of Streptocycline $(0.01 \%)+$ Copper oxychloride $(0.2 \%)$ was recommende by Mandal et al., (2017). Shahbaz et al., (2016) found treatment with copper oxychloride @ 1235 gm/ha to be at par with Trifloxystrobon + Tubeconazol @ $160 \mathrm{~g} / \mathrm{ha}$ in disease control. Application of newer chemicals like Amistar @ 0.1\%, Nativo 75 WG @ 0.65\% have been found effective against bacterial leaf blight disease of rice by several workers in the recent years (Mustafa et al., 2013; Razu and Hossain, 2016; Qudsia et al., 2017).

\section{Biological management}

The biological control of plant pathogens by antagonistic microorganisms is known to be a cheap, effective and eco-friendly method for the management of crop diseases (Cook and Baker, 1983). Pseudomonas and Trichoderma have been known for their potential to reduce the plant disease caused by fungal and bacterial pathogens (Pant and Mukhopadhyay, 2001). The bacterial antagonist Pseudomonas fluorescens strain 7-14, suppress both blast and sheath blight of rice (Gnanamanickam and Mew, 1992; Chatterjee et al., 1996; Krishnamurthy and Gnanamanickam, 1998). The use of antagonistic bacteria viz. Bacillus sp. for suppression of BLB of rice has been documented (Vasudevan, 2002).

Ark et al., (1986) reported that the antibacterial and antifungal activities of alcoholic plant extracts of barley and wheat seeds which significantly checked the growth of the tested bacterium. Rode et al., (1989) investigated that potential botanical extracts in different solvents of Allium ampeloprasum and $A$. sativum under in vitro conditions against bacteria and fungi, which showed 
significantly higher results as compared to the un-treated control as these extracts. Kazmi et al., (1991) tested different plant extracts for controlling the growth of Rhizoctonia solani and found aqueous extracts of neem seeds, $30 \%$ neem and garlic bulb $4 \%$ showed antifungal activity whereas neem oil at $0.1 \%$ was found more effective against tested fungi than benomil.

Resistance and susceptibility in rice to Xanthomonas oryzae pv. oryzae

The Bacterial leaf blight of rice caused by Xanthomonas oryzae pv. oryzae (Xoo) is known to be controlled by genetic resistance with over 40 resistance $(\mathrm{R})$ genes identified to control the disease (Verdier et al., 2011). Representatives of a major class of resistance genes ( $\mathrm{R}$ genes) against the disease that are prominent in rice are given the prefix $X a$ for Xanthomonas. The first $\mathrm{R}$ gene for bacterial blight as well as the first $\mathrm{R}$ gene of the receptor kinase (RLK) class to be cloned is $\mathrm{Xa21}$ which was introgressed into rice from the related species Oryza longistaminata at Central Rice Research Institute, Cuttack, India (Song et al., 1995). Xa21 confers broad spectrum resistance to several strains of Xoo (Ronald et al., 1992; Wang et al., 1996). RLKs have been shown to play a key role in a number of signaling pathways in plants, including innate immunity (Morillo and Tax, 2006).

A novel insight into $\mathrm{Xa21}$ mediated immunity in rice against Xanthomonas suggested that a sulfated peptide called ax YS22, derived from Xanthomonas oryzae secreted protein Ax 21 . This Ax21 being present in most Xanthomonas species was considered a PAMP and $X a 21$ a PRR that elicits $X a 21$ mediated resistance by binding to the LRR domain of the Xa21 protein (Lee et al., 2009). Extensive studies on $\mathrm{Xa} 21$ mediated signaling network have revealed important role of five
Xa21 binding proteins (XBs), including an ATPase (XB24), an E3 ubiquitin ligase (XB3), a PP2C phosphatase (XB15), a WRKY62 transcription factor (TF) (XB10) and an ankyrin-repeat protein (XB25), in regulating the rice defense response against Xanthomonas oryzae pv. oryzae (Chen et al., 2010; Jiang et al., 2013; Park et al., 2008; Peng et al., 2008; Wang et al., 2006). XB24 catalyzes the auto phosphorylation of serine and threonine residues on $\mathrm{Xa2l}$ and this modification is essential to keep $\mathrm{Xa21}$ in an inactive form. $\mathrm{Xa21}$ kinase disassociates from $\mathrm{XB} 24$ and it activates upon recognition of pathogen invasion (Chen et al., 2010). This activation triggers numerous downstream events that elicit the defense response. The Nterminal portion of XB25 physically interacts with the transmembrane domain of Xa21 through the binding to transmembrane and positively charged domain (BTMP) repeats of XB25 (Jiang et al., 2013). Down regulation of $\mathrm{Xb} 25$ reduces the levels of $\mathrm{Xa21}$ thus compromising the $\mathrm{Xa21}$ mediated resistance. Thus, several diverse proteins are involved in the activation of $\mathrm{Xa21}$ and signaling after pathogen recognition in rice (White and Yang, 2009).

Other members of the RLK family include Xa26 also conferring broad resistance to a rather different strain profile (Sun et al., 2004). FLS2 and EFR genes have been identified as components of the pathogenassociated molecular pattern triggered immunity (PTI) response (Gomez-Gomez and Boller, 2002; Zipfel et al., 2004). Xal represents another major class of $\mathrm{R}$ genes, the nucleotide-binding site (NBS)-LRR group (Yoshimura et al., 1998). The expression of $\mathrm{Xal}$ is regulated upon bacterial infection and where in $\mathrm{R}$ gene regulation is coordinated with other pathways for defense responses. $\mathrm{Xal}$ was found to be effective against some Xoo isolates in Japan but ineffective against most strains from the Philippines (Yoshimura 
et al., 1998; Zhang and Gassmann, 2007). $\mathrm{Xa27}$ is another gene that confers broad resistance and is representative of are class of dominant $\mathrm{R}$ genes in rice ( $\mathrm{Gu}$ et al., 2004), whose specificity is based on differential gene expression ( $\mathrm{Gu}$ et al., 2005). Xa4 was primarily derived from an Indian cultivar TKM6 and convene resistance in IR20 and other IR varieties, developed at IRRI (Khush et al., 1990; Zhang et al., 1998). Cao et al., (2007) reported substantial resistance against the disease imparted by $\mathrm{Xa3/Xa26}$ gene in rice at both seedling and adult stage (Liu et al., 2020).

Although it has been well known that most plant $\mathrm{R}$ genes are dominant, recessive genes have also been recognized in many hostpathogen interactions. Several recessive $R$ genes have been characterized from rice (Ogawa and Khush, 1988). Of these, 3 (xa5, $x a 8$ and $x a 13$ ) occur naturally and confer race-specific resistance. Another 3 (xa15, xa19 and xa20) have been induced by mutagenesis and each confers a wide spectrum of resistance (Iyer and Mc Couch, 2004; Jiang et al., 2006).

The recessive resistance gene, $x a 13$, has been identified by map-based cloning (Chu et al., 2005; Chu et al., 2006). The dominant allele $\mathrm{Xa13}$ was also named Os8N3 due to the location on rice chromosome 8 and the similarity to MtN3 [nodulin 3 (N3) protein of Medicago truncatula] (Gamas et al., 1996; Yang et al., 2006). It was recognized that the critical difference between resistant (xa13/xa13) and susceptible plants lies in the elevated expression of Os8N3 during bacterial infection in susceptible plant genotypes and the absence of Os8N3 induction during infection in the resistant genotypes (Yang et al., 2006; Yuan et al., 2009). Thus, Os8N3 is a gene for susceptibility that is exploited by $X o o$, and the xal3 allele occurs naturally for resistance (Yang et al., 2006).
There have been evidences in support of the strategy of pyramiding appropriate resistant genes to develop resistant cultivars. Gene combination $\mathrm{Xa4}+x a 5, x a 5+x a 2 l$ and $x a 4$ $+x a 5+x a 2 l$ confers broad spectrum resistance to numerous Xoo isolates (Saha et al., 2015). Marker assisted breeding strategy has also been found advantage in enhancing the resistance of elite cultivars (viz. Swarna and IR 64) to bacterial leaf blight by pyramiding few specific resistance genes (xa5, xa13 and Xa21) through backcrossing. The lines thus developed exhibited a wider and higher level of resistance as compared to lines with only a single gene (Huang et al., 1997; Sridhar et al., 2001; Saha et al., 2015).

\section{Durability of genetic resistance}

$\mathrm{R}$ genes stimulate a strong, usually racespecific, resistance response in host plant that results in development of small lesions, localized cell death or lack of susceptibility. The major constraint after deployment of these $\mathrm{R}$ genes is the fact that pathogen populations evolve rapidly in order to overcome the resistance. Durability of effective resistance is therefore, a continuing challenge for the control of bacterial leaf blight (Delorean, 2016).

In Effector triggered immunity (ETI) or the common $\mathrm{R}$ gene-mediated resistance, plant $\mathrm{R}$ proteins either directly recognize specific effectors or indirectly recognize the interference of the effectors through 'guardee' protein and this recognition leads to stimulation of resistance response.

This type of resistance is dependent on the pathogen's effectors and is pathogen racespecific. In the Xoo rice pathosystem, resistance results from recognition of Transcription Activator Like (TAL) virulence effectors by host R gene (Rao et al., 2002; Zhang and Wang, 2013). Xoo TAL effectors 
are interesting proteins because of their unusual structure and functions that affect plant processes in unique ways (Schornack et al., 2013). TAL effectors target host genes expression in order to manipulate their regulation in favor of pathogen development. In spite of intermittent differences, typically TALs are virulence effectors that activate host genes called susceptibility genes by binding to EBE in target gene promoters. Examples of susceptibility genes include copper and sugar transporters, transcription IIA subunits, and bZIP transcription factors (Iyer and McCouch, 2004; Sugio et al., 2007; Yuan et al., 2010; Streubel et al., 2013; Hutin et al., 2015).

In response, hosts too have evolved diverse resistance mechanisms to combat the action of TAL effectors. A majority of these include genetic mutations in the TAL target genes or their promoters. Mutations in the EBEs of susceptibility genes, for example, result in resistance because the mutations block activation of the genes. Recessive resistance genes $x a 13$ and $x a 25$, the two wellcharacterized $\mathrm{R}$ genes to Xoo possess such EBE mutations (Chu et al., 2006; Yuan et al., 2009; Zhou et al., 2015).

Some TALs directly activate resistance genes that regulate cell death for hypersensitive response. TAL effector Avr Xa27, for example, binds to an EBE in the promoter of the resistance gene $\mathrm{Xa27}$ and triggers a hypersensitive response ( $\mathrm{Gu}$ et al., 2005). The importance of TAL effectors in plant disease resistance is asserted by the cumulative understanding of TAL activity in hostpathogen interaction and the variations in mechanisms that evolved in plants to surpass TAL effectors.

This knowledge offers a basis for devising various strategies to overcome TAL effectorbased virulence, exploiting TAL effector- triggered resistance and using TAL effector fusion proteins to engineer genomes with the motive of aborting or limiting pathogen infection (Schornack et al., 2013).

\section{Structural and biochemical mechanism of resistance}

Besides, genetic resistance structural and biochemical resistance has also been suggested in rice against BLB (Khan, 2014; Saha et al., 2015). Rice cultivars with few, short, narrow and erect leaves have been shown to be less prone to BLB infection as compared to those having luxuriant growth and spreading leaves (Kiryu and Mazuta, 1995). Retention of more bacterial inoculums was high in rice cultivars with hairy leaves and these showed maximum disease while the disease was very low in cultivars with glabrous leaves (Dath et al., 1977). The stomatal index was usually lower in resistant varieties than susceptible ones (Shukla and Gangopadhyay, 1981). A negative correlation has been reported between BLB disease development and frequency of distribution of silicate cells in rice leaves (Kaul and Sharma, 1987). Resistant cultivars have a higher ratio of reducing sugars to total nitrogen, higher contents of polyphenols, lower contents of some free amino acids and produce some nonspecific phytoalexins (Mahto et al., 1987; Ou, 1985). The development of fibrillar material in rice plants has been reported to be a defense mechanism associated with hostpathogen interaction and causes immobilization of bacterial inoculum (Horino, 1981).

\section{References}

Ark, P.A., Bottirn, A.I. and Thompson, J.P. 1986. Sodium usnae as an antibiotic for plant diseases. Plant Disease., 44: 200-203.

Ashish., Arora, A., Gill, P.P.S., Jawandha, S.K. 2016. Effect of Agro chemicals on Severity of Bacterial Blight and Fruit Quality in 
Pomegranate. International Journal of Agriculture, Environment and Biotechnology., 9(6): 1061-1067.

Bala, A., Rai, B., Priya, S., Kumar, R. 2017. In vitro evaluation of various fungicides and plant extracts against Xanthomonas oryzae pv. oryzae isolated from rice (Oryzae sativa L.). International Journal of Current Microbiology and Applied Sciences., 6(5): 421-427.

Bhapkar, D.G., Kulkarni, N.B., Chavan, V.M. 1960. Bacterial blight of paddy. Poona Agricultural College Magazine., 51: 36-46.

Biswas, S.K.. Rai, M., Srivastava, S.S.L. 2009. Evaluation of antibiotics and their suitable use against bacterial blight of paddy [Xanthomonas oryzae Pv. oryzae (Ishiyama) Dye]. Indian Phytopathology., 62: 126-128.

Cao, Y., Ding, X., Cai, M., Zhao, J., Lin, Y., Li, X., Xu, C., Wang, S. 2007. The expression pattern of a rice disease resistance gene $x a 3 / x a 26$ is differentially regulated by the genetic backgrounds and developmental stages that influence its function. Genetics., 177(1): 523-533.

Chaudhary, S.U., Iqbal, J., Hussain, M. 2012. Effectiveness of Different fungicides and Antibiotics against Bacterial leaf blight in Rice. Journal of Agricultural Research., 50(1): 109-117.

Chauhan, H.L and Vaishnav, M.U 1980. Control of bacterial blight of rice caused by Xanthomonas oryzae. Indian Journal of Mycology and Plant Pathology, 10(1): 7779.

Chen, X., Chern, M., Canlas, P.E., Ruan, D., Jiang, C., Ronald, P.C. 2010. An ATPase promotes auto-phosphorylation of the pattern recognition receptor $X a 21$ and inhibits Xa2l-mediated immunity. Proceedings of the National Academy Sciences. USA., 107: 8029-34.

Chu, Z., Fu, B., Yang, H., Xu, C., Li, Z., Sanchez, A., Park, Y.J., Bennetzen, J. L., Zhang, Q., Wang, S. 2005. Targeting xal3, a recessive gene for bacterial blight resistance in rice. Theoretical and Appllied Genetics., 112: 455-461.

Chu, Z., Yuan, M., Yao, J., Ge, X., Yuan, B., Xu, C., Li, X., Fu, B., Li, Z., Bennetzen, J.L.
2006. Promoter mutations of an essential gene for pollen development result in disease resistance in rice. Genes Development., 20: 1250-1255.

Dath, P., Padmanabhan, S.Y., Devadath, S. 1977. The relation between certain host characters and bacterial blight incidence in rice. Proceeding of Indian Academy of Sciences., 85: 301-309.

Delorean, E.E. 2016. Detecting durable resistance to rice bacterial blight. Colorado State University Fort Collins, Colorado.

Gamas, P., Niebel, F.C., Lescure, N., Cullimore, J. 1996. Use of a subtractive hybridization approach to identify new Medicago truncatula genes induced during root nodule development. Moleular Plant Microbe Interaction., 9: 233-242.

Gangwar, G.P. 2013. Compatibility of bacterial bioagent of bacterial leaf blight of rice with chemical pesticides, commonly used in rice cultivation. International Journal of Agriculture innovations and Research., 2(2): 156-159.

Gangwar, G.P., Sinha, A.P. 2012. Effect of time of application of fungal and Bacterial antagonists on Bacterial leaf blight of rice. Agricultural Science Digest, 32(2): 123127.

Gnanamanickam, S.S., Priyadarisini, V.B., Narayanan, N.N., Vasudevan, P., Kavitha, S. 1999. An overview of Bacterial blight disease of rice and strategies for its management. Current Science. 77: 14351443.

Gomez-Gomez, L., Boller, T. 2002. Flagellin perception: a paradigm for innate immunity. Trends in Plant Science., 7: 251256.

Gu, K., Tian, D., Yang, F., Wu, L., Sreekala, C., Wang, D., Wang, G.L., Yin, Z. 2004. Highresolution genetic mapping of $X a 27(\mathrm{t})$, a new bacterial blight resistance gene in rice, Oryza sativa. L. Theoretical and Appllied Genetics., 108: 800-807.

Gu, K., Yang, B., Tian, D., Wu, L., Wang, D., Sreekala, C., Yang, F., Chu, Z., Wang, G.L., White, F.F. 2005. R gene expression induced by a type-III effector triggers disease resistance in rice. Nature., 435: 1122-1125. 
Horino, O. 1981. Ultrastructural histopathology of rice leaves infected with Xanthomonas campestris pv. oryzae on Kogyoku group rice varieties with different levels of resistance at seedling stage. Annuals of Phytopathology Society Japan., 47: 501509.

Huang, N., Angeles, E.R., Domingo, J., Mag Pantay, G., Singh, S., Zhang, G., Kumaradivel, N., Bennett, J., Khush, G.S. 1997. Pyramiding of bacterial blight resistant genes in rice: Marker assisted selection using RFLP and PLR. Theoretical and Applied Genetics., 95: 313-320.

Hutin, M., Sabot, F., Ghesquière, A. 2015. A knowledge-based molecular screen uncovers a broad spectrum OsSWEET14 resistance allele to bacterial blight from wild rice. Plant Journal., 84: 694-703.

Iyer, A.S., McCouch, S.R. 2004. The rice bacterial blight resistance gene $x a 5$ encodes a novel form of disease resistance. Molecular Plant Microbe Interaction., 17: 1348-1354.

Jadhav, R.R., More, A.S., Apet, K.T., Dandnaik, B.P. 2018. In vitro Bioefficacy of Different Antibiotics, Fungicides and Botanicals against (Xanthomonas axonopodis pv. citri.) causing Bacterial canker of Kagzi Lime. International Journal of Current Microbiology and Applied Sciences., 6: 1693-1699.

Jagtap, G.P, Jangam, A.M., Dey, U. 2012. Management of bacterial blight of cotton caused by Xanthomonas axonopodis pv. malvacearum. Scientific Journal of Microbiology., 1(1): 10-18.

Jain, S.S. 1970. Relation efficacy of some chemicals against bacterial leaf blight of rice caused by Xanthomonas oryzae (Uyeda and Ishiyama) Oryza., 7: 19-32.

Jarial, K., jarial, R.S., Sharma, D., Kumar, S., Dogra, B.S. 2015. Strategy for the management of Bacterial spot of bottle gourd caused by Xanthomonas cucurbitae under low hill condition of Himachal Pradesh. International Journal of Bioresource and Stress Management., 6(6): 744-748.

Jiang, G.H., Xia, Z.H., Zhou, Y.L., Wan, J., Li, D.Y., Chen, R.S., Zhai, W.X., Zhu, L.H.
2006. Testifying the rice bacterial blight resistance gene $x a 5$ by genetic complementation and further analyzing xa5 (Xa5) in comparison with its homolog TFII Agamma1. Molecular Genetics and Genomics., 275: 354-366.

Jiang, Y., Chen, X., Ding, X., Wang, Y., Chen, Q., Song, W.Y. 2013. The Xa21 binding protein $X B 25$ is required for maintaining Xa21-mediated disease resistance. Plant Journal., 73:814-23.

Kamble, A.K., Sanjay, S.D, Sujoy, S., Indu, S.S. 2017. In vitro efficacy of different chemicals and Biological agent against Xanthomonas campestris pv. viticola vausing Bacterial leaf spot of Grapes. International Journal of Agriculture Sciences, 9: 4427-4430.

Kaul, M.L.H., Sharma, K.K. 1987. Bacterial blight in Rice: A review. Biol. Zent. Bl., 106: 141-167.

Kazmi, S.A.R., Jilani, G. and Solangi, A.H. I991. Phyto-chemical variation and biological efficacy of the Neern tree.Technical Report,Tropical Agricultural Research Institute, Karachi University. Karachi. 3: 19-20.

Khan, J.A., Afroz, S., Arshad, H.M.I., Sarwar, N., Anwar, H.S., Saleem, K., Babar, M.M., Jamil, F.F. 2014. Biochemical basis of resistance in rice against Bacterial leaf blight disease caused by Xanthomonas oryzae pv. oryzae. Advances in Life Sciences., 1(3): 181-190.

Khan, M., Rafi, A., Abbas, A., Ali, T., Hassan, A. 2015. Assessment of yield losses caused by Bacterial blight of rice in upper dir, Khyber pakhtunkhwa province. Asian Journal Agricultural Biology., 3(2): 74-78.

Khan, T.U.Z., Yasin, S.I., Ayub, M., Shah, J.A., Ahmad, M. 2005. Effect of different chemicals and antibiotics on Bacterial leaf blight (Xanthomonas oryzae pv. oryzae) of rice. Mycopathology., 3(1\&2): 57-59.

Khush, G.S., Bacalongo, E and Ogawa, T. 1990. A new gene for resistance to bacterial blight from Oryza longistaminatia. Rice Genetics Newsletter., 7: 121122.

Kiryu, T., Mizuta, H. 1995. On the relation between habits of rice and varietal resistance of bacterial leaf blight. Kyushu 
Agricultural Research, 15: 54-56.

Kulkarni, S., Jahagirdar, S. 2011. Evaluation of new molecules in the management of bacterial leaf blight of paddy in India. International Journal of Plant Protection, 4(2): 289-291.

Kumar, M., Parate, R.L., Ninawe, B.N. 2009. Effect of botanicals, bioagents and some chemicals against Xantomonas oryzae pv. oryzae. Journal of Plant Disease Science., 4(1): 60-63.

Kumar, S., Meshram, S., Sinha, A. 2017. Bacterial disease in rice and their eco-friendly management. International journal of Agricultural Science and Research., 7: 3142.

Lee, S.W., Han, S.W., Sririyanum, M., Park, C.J., Seo, Y.S., Ronald, P.C. 2009. A type Isecreted, sulfated peptide triggers Xa21mediated innate immunity. Science., 326:850-53.

Li, Zhi-Kang., Sanchez, A., Angeles, E., Singh, S., Domingo, J., Huang, N., Khush, G.S. 2001. Are the Dominant and Recessive Plant Disease Resistance Genes Similar?: A Case Study of Rice $\mathrm{R}$ Genes and Xanthomonas oryzae pv. oryzae Races. Genetics., 159: 757-765.

Liu, F., Zhang, W., Schwessinger, B., Wei, T., Ruan, D., Ronald, P. 2020. The Rice $\mathrm{Xa} 3$ Gene Confers Resistance to Xanthomonas oryzae pv. oryzae in the Model Rice Kitaake Genetic Background. Frontiers in plant science., 11: 49.

Liu, W., Liu, J., Triplett, L., Leach, J.E., Wang Guo-Liang. 2014. Novel Insights into Rice Innate Immunity Against Bacterial and Fungal Pathogens. Annual Review of Phytopathology., 52: 213-41.

Mahto, B.N., Singh, R.N., Awasthi, C.P., Abidi, A.B. 1987. Sugars and phenolics compounds in rice leaves in relation to varietal resistance to bacterial blight (BB) pathogen. International Rice Research Institute. Newsletter., 12: 12-13.

Mandal, D., Pal, R., Mohanty, A.K. 2017. Management of Bacterial leaf blight of rice in an integrated way. Journal of Mycopathological Research., 54(4): 539541.
Meena, S.C., Chattopadhyay, A., Meena, M.K., Shah, R., Rawal., Mali, B.L. 2017. Integration of chemicals and Botanicals for the management of Pomegranate Bacterial blight caused by Xanthomonas axonopodis pv. punicae. Indian Journal of Mycology and Plant Pathology, 47(1): 27-35.

Mew, T.W. 1987. Current status and future prospects of research on Bacterial blight of rice. Annual Review Phytopathology., 25: 359-382.

Mew, T.W., Alwarez, A.M., Leach, J.E., Swings, J. 1993. Focus on bacterial blight of rice. Plant Disease., 77(1): 5-12.

Morillo, S.A., Tax, F.E. 2006. Functional analysis of receptor-like kinases in monocots and dicots. Current Opinion in Plant Biology., 9:460-469.

Mouria, A., Hmouni, A., Mouria, B., Touhami, A.O., benkirane, R., Semaoui, K., Douira, A. 2017. Efficiency of selected fungicides on Blast and Blight of rice leaves. Asian Journal of Advances in Agricultural Research, 1(1): 1-9.

Mouria, A., Hmouni, A., Mouria, B., Touhami, A.O., benkirane, R., Semaoui, K., Douira, A. 2017. Efficiency of selected fungicides on Blast and Blight of rice leaves. Asian Journal of Advances in Agricultural Research., 1(1): 1-9.

Mubassir, M.H.M., Nasiruddin, K.M., Shahin, N.H., Begum, S.N., Sultana, A., Rashid, A.Q.M.B. 2016. Measurement of Phenotypic Variation for Control and Bacterial Leaf Blight Inoculated Rice Lines and Varieties. American Journal of Bioscience and Bioengineering., 4(6): 5964.

Mustafa, A., Yasin, S.I., Mahmood, S., Hannan, A., Akhtar, M. 2013. Field Evaluation of new Fungicide against rice disease. Pakistan Journal of Phytopathology., 25(2): 141-145.

Nino-Liu, D.O., Ronald, P.C., Bogdanove, A.J. 2006. Xanthomonas oryzae pathovars: model pathogens of a model crops. Molecular Plant Pathology., 7(5): 303- 324.

Ogawa, T., Khush, G.S. 1988. Major genes for resistance to bacterial blight in rice. In: Bacterial Blight of Rice, Proceedings of the International Workshop on Bacterial Blight 
of Rice. International Rice Research Institute, Manila, Philippines, pp. 177-192.

Ou, S.H. 1977. Possible presence of bacterial blight in latin America. International Rice Research Notes., 2: 5-6.

Ou, S.H. 1985. Rice diseases ( $\left.2^{\text {nd }} E d n\right)$, Common wealth Mycological Institute, New England pp. 370.

Park, C.J., Peng, Y., Chen, X., Dardick, C., Ruan, D. 2008. Rice XB15, a protein phosphatase $2 \mathrm{C}$, negatively regulates cell death and Xa21-mediated innate immunity. PLoS Biology., 6: 231.

Parthasarathy, R., Indira, J., Appu, Manikandan. A. and Karthikeyan, A. 2014. To study the antagonistic organism and new chemicals against the bacterial blight pathogen (Xanthomonas oryzae pv. oryzae) of rice. International Journal of Research in Biotechnology and Biochemistry., 4: 6-11.

Patel, S.J., Chauhan, H.L., Mehta, A.N., Gohil, N.M. 2009. Management of bacterial blight of rice with chemicals, botanicals and antagonists. Journal of Plant Disease Sciences, 4(2): 208-211.

Peng, Y., Bartley, L.E., Chen, X.W., Dardick, C., Chern, M.S. 2008. OsWRKY62 is a negative regulator of basal and Xa21mediated defense against Xanthomonas oryzae pv. oryzae in rice. Molecular Plant Pathology., 1: 446-58.

Prasad, D., Singh, R., Deep, S. 2018. In-vitro and In-vivo Efficacy of Antibacterial Compounds against Xanthomonas oryzae pv. oryzae, A Cause of Bacterial Leaf Blight of Rice. International Journal of Current Microbiology and Applied Sciences., 7(5): 2960-2969.

Qudsia, H., Akhter, M., Riaz, A., Haider, Z., Abid, M. 2017. Comparative Efficacy of Different Chemical Treatments for Paddy Blast, Brown Leaf Spot and Bacterial Leaf Blight Diseases in Rice (Oryza sativa L.). Applied Microbiology., DOI: 10.4172/2471-93151000138.

Rafi, A., Hameed, A., Akhtar, M.D., Shah, S.M.A., Junaidi, M., Shahid, M., Shah, S.F. 2013. Field based assessement of rice Bacterial leaf blight in major rice growing zones of Pakistan. Sarhad Journal of Agriculture., 29(3): 415-422.
Rao K., Lakshminarasu, M., Jena, K.K. 2002. DNA markers and marker-assisted breeding for durable resistance to bacterial blight disease in rice. Biotechnology Advances., 20: 33-47.

Razu, M.A.U., Hossain, I. 2016. Effect of biocontrol agent, plant extracts and chemicals on disease incidence of rice. Bangladesh Phytopathological Society., 32: 33-36.

Rode, H., Wet, P.M. and Cywer, S. 1989. The antimicrobial effect of Allium sativm L. garlic. African Journal of Agricultural Research., 85: 460-464.

Ronald, P.C., Albano, B., Tabien, R., Abenes, L., Wu, K., McCouch, S., Tanksley, S.D. 1992. Genetic and physical analysis of the rice bacterial blight disease resistance locus, Xa21. Molecular Genetics and Genomics., 236: 113-120.

Saha, S., Garg, R., Biswas, A., Rai, A.B. 2015. Bacterial Diseases of Rice: An Overview. Journal of Pure and Applied Microbiology., 9(1): 725-736.

Schornack, S., Moscou, M.J., Ward, E.R., Horvath, D.M. 2013. Engineering Plant Disease Resistance Based on TAL Effectors. Annual Review of Phytopathology., 51: 383-406.

Shahbaz, M., Ahmad, F., Muhammad, S., Javed, M.A., Waqar, M.Q., Ali, M.A. 2016. Efficacy of different chemicals for the management of Bacterial leaf blight of rice (Oryzae sativa L.) at various locations of adaptive research zone Sheikhupura. Pakistan Journal of Phytopathology., 28(2): 223-230.

Sharma, P., Bora, L.C., Puzaril, K.C., Baruah, A.M., Baruah, R., Talukdar, K., Kataky, L., Phukan, A. 2017. Review on Bacterial Blight of rice caused by Xanthomonas oryzae pv. oryzae: Different management approaches and role of Pseudomonas fluorescens as a potential Biocontrol agent. International Journal of Current Microbiology and Applied Sciences., 6: 982-1005.

Shukla, S.N., Gangopadhyay, S. 1981. Stomatal index and size of stomatal opening of rice cultivars varying in reaction to bacterial leaf blight. Proceeding of the Indian National Sciences Academy., 47: 557-559. 
Singh, R., Yadav, R.S., Javeria, S. 2015. Management of bacterial leaf blight of Basmati rice caused by Xanthomonas oryzae pv. oryzae with some available antibiotics and plant products. International Journal of Innovative and Applied Research., 3(11): 1-6.

Song, W., Wang, G., Chen, L., Kim, H., Pi, L., Holsten, T., Gardner, J., Wang, B., Zhai, W., Zhu, L. 1995.A receptor kinase-like protein encoded by the rice disease resistance gene, Xa21. Science., 270: 18041806.

Sridhar, R., Redd, R.N., Shanti, M.L., Singh, U.D. 2001. Characterization of rice bacterial blight pathogen isolates from eastern India and breeding for bacterial resistance by molecular tools. In : Role of resistance in Intensive Agriculture, Nagarajan, S., Singh, D.P., , Kalyani Publishers, India., edition 183-194.

Srinivasan, M.C., Thirmulachar, M.J., Patel, M.K. 1959. Bacterial blight of rice. Current Science., 28: 469-470.

Srivastava, D.N. 1967. Epidemiology and control of BLB of rice in India. In: proceedings of asymposium in rice diseases and their control by growing resistant varieties and other measures. Japan Agriculture, Forestry and Fisheries Research Council., 11:18.

Streubel, J., Pesce, C., Hutin, M. 2013. Five phylogenetically close rice SWEET genes confer TAL effector mediated susceptibility to Xanthomonas oryzae pv. oryzae. New Phytologist., 200: 808-819.

Sugio, A., Yang, B., Zhu, T., White, F.F. 2007. Two type III effector genes of Xanthomonas oryzae pv. oryzae control the induction of the host genes OsTFIIA $\gamma 1$ and OsTFX1 during bacterial blight of rice. Proceeding of the Indian National Sciences Academy USA., 104: 10720-10725.

Sun, X., Cao, Y., Yang, Z., Xu, C., Li, X., Wang, S., Zhang, Q. 2004. Xa26, a gene conferring resistance to Xanthomonas oryzae pv. oryzae in rice, encodes an LRR receptor kinase-like protein. Plant Journal, 37: 517527.

Swati., Kumar, A., Roy, S.P., Kumari, P. 2015. studies on efficacy of different chemicals treatments against Bacterial leaf blight of rice in Bihar. An Internatinational Quarterly Journal of Life Sciences., 2(1\&2): 56-61.

Swings J, Mooter MV, Vauterin L, Hoste B, Gillis M, Mew TW, Kersters K. Reclassification of the causal agents of bacterial blight of rice (Xanthomonas campestrispv. oryzae) and bacterial leaf streak (Xanthomonas campestris pv. oryzicola) of rice as pathovars of Xanthomonas oryzae. International Journal of Systematic Bacteriology.1990; 40: 309-311.

Tabei, H. 1967. Anatomical studies of rice plant affected with bacterial leaf blight, with special reference to stomatal infection at the coleoptile and the foliage leaf sheath of rice seedling. Annals Phytopathological Society Japan., 33: 12-16.

Tabei, H., and Mukoo, H. 1960. Anatomical studies of rice plant leaves affected with bacterial leaf blight in particular reference to the structure of water exudation system. Bulletin of National Inst. Agric. Sci. Japan. 11: 37-43.

Tagami, Y. and Mizukami, T. 1962. Review of the researches on bank roll leaf blight of rice caused by Xanthomonas oryzae. Special report of the plant disease and insect pests forecasting service no. 10. Plant Prot. Div. Ministry Agric. For. Tokyo Japan. pp. 112.

Thimmegowda, P.R., Sataraddi, A., Ambika, D.S., Prasad, P.S., Chandrashekhar, M. 2012. Efficacy of Antibiotics and Biorational Pesticides against Bacterial Blight of Paddy. Madras Agricultural Journal., 99(79): 592-596.

Verdier, V., Vera, C.C., Leach, J.E. 2011. Controlling rice bacterial blight in Africa: needs and prospects. Journal of Biotechnology., 159: 320-28.

Wang, G., Song, W., Ruan, D., Sideris, S., Ronald, P.C. 1996. The cloned gene, Xa21, confers resistance to multiple Xanthomonas oryzae pv. oryzae isolates in transgenic plants. Molecular Plant Microbe Interactions., 9: 850-855.

Wang, Y.S., Pi, L.Y., Chen, X.H., Chakrabarty, P.K., Jiang, J. 2006. Rice Xa21 binding protein 3 is an ubiquitin ligase required for 
full Xa21-mediated disease resistance. Plant Cell., 18: 3635-46.

White, F.F and Yang, B. 2009. Host and Pathogen Factors Controlling the Rice-Xanthomonas oryzae Interaction. Plant Physiology, 150:1677-1686.

Yamanuki, S., Nakamura, K., Kayano, M., Narita, T. and Iwata, T. 1962. First occurrence of bacterial leaf blight of rice in Hokkaido. Annual Phytopathology., 27: 264.

Yang, B., Sugio, A., White, F.F. 2006. Os8N3 is a host disease-susceptibility gene for bacterial blight of rice. Proceeding of the Indian National Sciences Academy USA., 103: 10503-10508.

Yoshimura, S., Yamanouchi, U., Katayose, Y., Toki, S., Wang, Z., Kono, I., Yano, M., Iwata, N., Sasaki, T. 1998. Expression of $\mathrm{Xal}$, a bacterial blight resistance gene in rice, is induced by bacterial inoculation. Proceeding of the Indian National Sciences Academy USA., 95: 1663-1668.

Yuan, M., Chu, Z., Li, X. 2010. The bacterial pathogen Xanthomonas oryzae overcomes rice defenses by regulating host copper redistribution. Plant Cell., 22: 3164-3176.

Yuan, M., Chu, Z., Li, X., Xu, C., Wang, S. 2009. Pathogen-induced expressional loss of function is the key factor of race-specific bacterial resistance conferred by a recessive $\mathrm{R}$ gene xal3 in rice. Plant Cell Physiology.,
50: 947-955.

Zhang, G.F., Chang, H.M., Lu, C and Wang, K.R. 1998. Study on the control technology of rice bacterial leaf blight (Xanthomonas oryzae). Phytophyl. Sin, 25: 295-299.

Zhang, G.G., Lu, C.T., Sheng, Z.C., Kong, J. 1996. Application methods of zhongshengmycin (a substance metabolized Streptomycin lavendula var. hoenaensis) in controlling rice bacterial leaf blight (Xanthomonas oryaze) progress research on plant protection in China. Proc. Third Nat. Conf. Integr. Pest Manage. pp. 167-169.

Zhang, H., Wang, S. 2013. Rice versus Xanthomonas oryzae pv. oryzae: a unique pathosystem. Current Opinion in Plant Biology., 16:188-195.

Zhang, X.C., Gassmann, W. 2007. Alternative splicing and mRNA levels of the disease resistance gene RPS4 are induced during defense responses. Plant Physiology, 145: 1577-1587.

Zhou, J., Peng, Z., Long, J. 2015. Gene targeting by the TAL effector PthXo2 reveals cryptic resistance gene for bacterial blight of rice. Plant Journal., 82:632-643.

Zipfel, C., Robatzek, S., Navarro, L., Oakeley, E.J., Jones, J.D., Felix, G., Boller, T. 2004. Bacterial disease resistance in Arabidopsis through flagellin perception. Nature., 428: 764-767.

\section{How to cite this article:}

Sumit Shekhar, Diksha Sinha and Anita Kumari. 2020. An Overview of Bacterial Leaf Blight Disease of Rice and Different Strategies for its Management. Int.J.Curr.Microbiol.App.Sci. 9(04): 2250-2265. doi: https://doi.org/10.20546/ijcmas.2020.904.270 